\title{
Sann-Joong-Kuey-Jian-Tang inhibits hepatocellular carcinoma Hep-G2 cell proliferation by increasing TNF- $\alpha$, Caspase-8, Caspase- 3 and Bax but by decreasing TCTP and Mcl-1 expression in vitro
}

\author{
YAO-LI CHEN $^{1 *}$, MENG-YI YAN $^{1 *}$, SU-YU CHIEN $^{4}$, SHOU-JEN KUO $^{1,3}$, DAR-REN CHEN $^{1,3}$, \\ CHUN-YUAN CHENG ${ }^{1}$ and CHIN-CHENG SU ${ }^{1,2,3,5}$ \\ ${ }^{1}$ Department of Surgery; ${ }^{2}$ Tumor Research Center of Integrative Medicine; ${ }^{3}$ Comprehensive Breast Cancer Center; \\ ${ }^{4}$ Department of Pharmacy, Changhua Christian Hospital, Changhua 500-06; ${ }^{5}$ School of Chinese Medicine, \\ College of Chinese Medicine, China Medical University, Taichung 40402, Taiwan, R.O.C.
}

Received November 13, 2012; Accepted March 4, 2013

DOI: $10.3892 / \mathrm{mmr} .2013 .1381$

\begin{abstract}
Hepatic cancer remains a challenging disease and there is a need to identify new treatments. Sann-Joong-KueyJian-Tang (SJKJT), a traditional medicinal prescription, has been used to treat lymphadenopathy and exhibits cytotoxic activity in many types of human cancer cells. Our previous studies revealed that SJKJT is capable of inhibiting colon cancer colo 205 cells by inducing autophagy and apoptosis. However, the effects and molecular mechanisms of SJKJT in human hepatocellular carcinoma have not been clearly elucidated. In the present study we evaluated the effects of SJKJT in human hepatic cellular carcinoma Hep-G2 cells. The cytotoxicity of SJKJT in Hep-G2 cells was measured by MTT assay. The cell cycles were analyzed by fluorescence-activated cell sorting (FACS). The protein expression of translationally controlled tumor protein (TCTP), Mcl-1, Fas, TNF- $\alpha$, Caspase-8, Caspase-3 and Bax in Hep-G2 cells treated with SJKJT was evaluated by western blotting. The protein expression of Caspase-3 was also detected by immunofluorescence staining. The results showed that SJKJT inhibits Hep-G2 cells in a time- and dose-dependent manner. During SJKJT treatment for 48 and $72 \mathrm{~h}$, the half-maximum inhibitory concentration $\left(\mathrm{IC}_{50}\right)$ was 1.48 and $0.94 \mathrm{mg} / \mathrm{ml}$, respectively. The FACS results revealed that increased doses of SJKJT were capable of increasing the percentage of cells in the sub-G1
\end{abstract}

Correspondence to: Dr Chin-Cheng Su, Tumor Research Center of Integrative Medicine, Department of Surgery, Comprehensive Breast Cancer Center, Changhua Christian Hospital, No. 135 Nan-Hsiao Street, Changhua City, Changhua County 500-06, Taiwan R.O.C.

E-mail: succ.maeva@msa.hinet.net

*Contributed equally

Key words: Sann-Joong-Kuey-Jian-Tang, Hep-G2 cells, apoptosis, TCTP, TNF- $\alpha$ phase. Immunofluorescence staining showed that Hep-G2 treated with SJKJT had increased expression of Caspase-3. The western blot results showed that the protein expression of Fas, TNF- $\alpha$, Caspase-8, Caspase- 3 and Bax was upregulated, but that of TCTP and Mcl-1 was downregulated in Hep-G2 cells treated with SJKJT. In conclusion, these findings indicated that SJKJT inhibits Hep-G2 cells. One of the molecular mechanisms responsible for this may be the increased Fas, TNF- $\alpha$, Caspase-8, Caspase- 3 and Bax expression; another mechanism may be via decreasing TCTP and Mcl-1 expression in order to induce apoptosis.

\section{Introduction}

In 2008, the estimated number of deaths from malignant liver tumors was 47,830 in males; hepatic cancer is the second most common cause of cancer-related mortality worldwide (1). In 2010 , cancers of the liver and intrahepatic bile ducts were also the leading cause of cancer-related mortality in males $(36.8 / 100,000)$ in Taiwan (2). As hepatocellular carcinoma (HCC) is resistant to many of the available chemotherapeutic agents, HCC remains a challenging disease to treat worldwide (3). Sann-Joong-Kuey-Jian-Tang (SJKJT), a traditional Chinese medicine, has been prescribed as complementary medication for a number of types of solid cancer in Taiwan. SJKJT consists of 17 species of medicinal herbs: Coptis chinensis Franch, Cimicifuga heracleifolia Komar, Scutellaria baicalensis Georgi, Gentiana scabra Bunge, Trichosanthes cucumeroides Maxim, Phellodendron amurense Rupr, Anemarrhena asphodeloides Bunge, Platycodon grandiflorum, Laminaria japonica Aresch, Bupleurum scorzoneri folium Willd (Bupleurum Chinese DC), Glycyrrhiza uralensis Fisch, Sparganium toloniferum Buch, Curcuma aeruginosa Roxb, Forsythia suspense Vahl, Pueraria lobata Ohwi, Paeonia lactiflora Pall and Angelica sinensis Diels (4). In our previous studies, it was shown that SJKJT inhibits colon cancer colo 205 cells by inducing autophagy in vitro (5) or increasing TNF- $\alpha$ expression to induce apoptosis in vitro and 
in vivo (6). However, the anticancer effects of SJKJT in hepatic cancer have not been understood. The present study focused on the anticancer effect and molecular mechanisms of SJKJT in HCC, using human hepatocellular carcinoma Hep-G2 cells.

\section{Materials and methods}

Materials. The crude extract of SJKJT was obtained from Chuang Song Zong Pharmaceutical Co., Ltd. (Ligang Plant, Taiwan). [3-(4,5-dimethylthiazol-2-y1)-2,5-diphenyltetrazolium bromide] MTT, sodium deoxycholate, leupeptin, Triton X-100, Tris-HCl, ribonuclease-A, sodium pyruvate, HEPES, dimethyl sulfoxide (DMSO) and RPMI-1640 were obtained from Sigma-Aldrich (St. Louis, MO, USA). The Hep-G2 human hepatic cancer cell line (BCRC number: 60025) was obtained from the Food Industry Research and Development Institute (Hsinchu, Taiwan). Potassium phosphate and TE buffer were purchased from Merck Co. (Darmstadt, Germany). Fetal bovine serum (FBS) and glutamine were obtained from Gibco BRL (Grand Island, NY, USA). Mouse anti- $\beta$-actin and penicillin-streptomycin were obtained from Sigma-Aldrich. BioMax film was obtained from Kodak. The FADD (no. 2782), Bax (no. 2774), Bcl-xL (no. 2764), Mcl-1 (no. 2764), TCTP (no. 2764), Caspase-8 (no. 9502) and TNF- $\alpha$ (no. 3707) antibodies were all obtained from Cell Signaling Technology Inc. (Beverly, MA, USA). Fas (NB120-13550) and Caspase-3 (NB500-210) antibodies were obtained from Novus Biologicals (Littleton, CO, USA). Other materials and reagents not specified were obtained from Sigma or Merck.

Cell culture. The Hep-G2 cells were obtained from the Food Industry Research and Development Institute (Hsinchu, Taiwan), and maintained in RPMI-1640 medium containing $10 \%$ FBS and $1 \%$ penicillin/streptomycin $(10,000 \mathrm{U} / \mathrm{ml}$ penicillin, $10 \mathrm{mg} / \mathrm{ml}$ streptomycin) at $37^{\circ} \mathrm{C}$ in a humidified atmosphere containing $5 \% \mathrm{CO}_{2}$.

Cytotoxicity assay. The cells were plated in 96-well plates at a density of $1 \times 10^{4}$ cells/well for $16-20 \mathrm{~h}$. Thereafter, the cells were treated with various concentrations of SJKJT for 24, 48 and $72 \mathrm{~h}$. Subsequently, the cells were incubated with $1 \mathrm{mg} / \mathrm{ml}$ of MTT in fresh RPMI medium for $2 \mathrm{~h}$. The surviving cells converted MTT to formazan by forming a blue-purple color when dissolved in DMSO. The intensity of formazan was measured at $590 \mathrm{~nm}$ using a microplate reader. The relative percentage of cell viability was calculated by dividing the absorbance of treated cells by that of the control in each experiment.

Cell cycle analysis. Hep-G2 cells treated with various concentrations of SJKJT for different durations were measured using a flow cytometer.

Hep-G2 cells were treated with various concentrations $(0,0.75,1$ and $1.5 \mathrm{mg} / \mathrm{ml})$ of SJKJT for $48 \mathrm{~h}$ or with various concentrations $(0,0.5,0.75$ and $1 \mathrm{mg} / \mathrm{ml})$ of SJKJT for $72 \mathrm{~h}$, and then collected and fixed with ice-cold ethanol (70\%) overnight at $-20^{\circ} \mathrm{C}$. The cell pellets were then treated with propidium iodide (PI) solutions (containing $100 \mu \mathrm{g} / \mathrm{ml}$ RNase) for $30 \mathrm{~min}$ at $37^{\circ} \mathrm{C}$. Subsequently, the samples were analyzed by a Cytomics ${ }^{\mathrm{TM}}$ FC500 Flow Cytometer (Beckman Coulter, Miami, FL, USA). A minimum of 10,000 cells was analyzed to determine DNA content, and the percentage of cells in each cell cycle phase was quantified.

Immunocytochemical staining. Hep-G2 cells were treated with various concentrations $(0,0.75,1$ and $1.5 \mathrm{mg} / \mathrm{ml})$ of SJKJT for $48 \mathrm{~h}$ or with various concentrations $(0,0.5,0.75$ and $1 \mathrm{mg} / \mathrm{ml}$ ) of SJKJT for $72 \mathrm{~h}$, and then washed with PBS. Fixation with 50\% acetone and 50\% methanol solution overnight at $4^{\circ} \mathrm{C}$ was performed, the cells were washed three times with PBS, and non-specific binding sites were blocked in PBS containing $0.1 \%$ BSA for $1 \mathrm{~h}$ at room temperature. Thereafter, the cells were separately incubated with rabbit anti-caspase 3 (1:20) antibody in PBS containing 0.1\% BSA overnight at $4^{\circ} \mathrm{C}$, and washed three times with PBS. The cells were then incubated with anti-rabbit FITC (1:200) in PBS containing $0.1 \%$ BSA for $1 \mathrm{~h}$ at room temperature, and washed three times with PBS. The nuclei were stained with $5 \mu \mathrm{g} / \mathrm{ml}$ PI, respectively. After staining, the samples were immediately examined under an Olympus IX81 microscope (Olympus, Tokyo, Japan).

Western blotting. The effects of SJKJT on the protein expression of Fas, TNF- $\alpha$, FADD, Caspase-8, Bax, Caspase-3, Mcl-1, TCTP and Bcl-xl in Hep-G2 cells was measured by western blotting.

Hep-G2 cells were treated with various concentrations $(0,0.75,1$ and $1.5 \mathrm{mg} / \mathrm{ml})$ of SJKJT for $48 \mathrm{~h}$ and the protein expression levels of Fas, TNF- $\alpha$, FADD, Caspase-8, Bax, Caspase-3, Mcl-1, TCTP and Bcl-xl were evaluated by western blotting.

Hep-G2 cells were treated with various concentrations $(0,0.5,0.75$ and $1 \mathrm{mg} / \mathrm{ml})$ of SJKJT for $72 \mathrm{~h}$ and the protein expression levels of Fas, TNF- $\alpha$, FADD, Caspase-8, Bax, Caspase-3, Mcl-1, TCTP and Bcl-xl were evaluated by western blotting.

Hep-G2 cells were treated with SJKJT $(1 \mathrm{mg} / \mathrm{ml})$ for different durations $(0,24,48$ and $72 \mathrm{~h})$ and then the protein expression levels of Bcl-xl, Mcl-1, TCTP and Bax were evaluated by western blotting.

Following the termination of drug treatment, the cells were lysed in ice-cold whole cell extract buffer containing the protease inhibitors. The lysate was vibrated for $30 \mathrm{~min}$ at $4^{\circ} \mathrm{C}$ and centrifuged at $9.4 \times \mathrm{g}$ for $10 \mathrm{~min}$. Protein concentration was measured using a BCA protein assay kit (Pierce, Rockford, IL, USA). Equal amounts of proteins were subjected to electrophoresis using $12 \%$ sodium dodecyl sulfate-polyacrylamide gels. To verify equal protein loading and transfer, proteins were then transferred to polyvinylidene difluoride membranes and the membranes were blocked overnight at $4^{\circ} \mathrm{C}$ using blocking buffer [5\% non-fat dried milk in solution containing $50 \mathrm{mM}$ Tris/ $\mathrm{HCl}(\mathrm{pH} 8.0), 2 \mathrm{mM} \mathrm{CaCl}_{2}$, $80 \mathrm{mM}$ sodium chloride, $0.05 \%$ Tween 20 and $0.02 \%$ sodium azide]. The membranes were then incubated for $2 \mathrm{~h}$ at $25^{\circ} \mathrm{C}$ with specific primary antibody followed by anti-rabbit or anti-mouse immunoglobulin G-horseradish peroxidase conjugated secondary antibodies. The membranes were washed three times for 10 min with washing solution. The protein bands were then visualized on X-ray film using the enhanced chemiluminescence detection system (PerkinElmer Life and Analytical Sciences, Boston, MA, USA). 


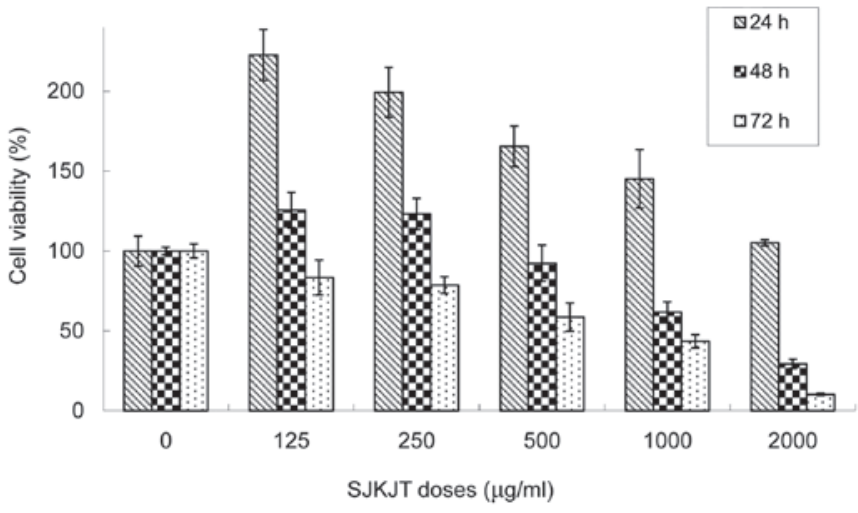

Figure 1 . The cytotoxicity of SJKJT in Hep-G2 cells. The cytotoxicity of SJKJT in Hep-G2 cells was determined using the MTT assay as described in Materials and methods. SJKJT significantly inhibited Hep-G2 cell proliferation in a time- and dose-dependent manner. Each point is the mean $\pm \mathrm{SD}$ of three experiments. SJKJT, Sann-Joong-Kuey-Jian-Tang.

Statistical analysis. Values were presented as the means \pm standard deviation (SD). The Student's t-test was used to analyze statistical significance. $\mathrm{P}<0.05$ was considered to indicate a statistically significant difference for all the tests.

\section{Results and Discussion}

The effects of SJKJT on the viability of Hep-G2 cells. Our results revealed that SJKJT inhibits the proliferation of Hep-G2 cells in a time- and dose-dependent manner. The half-maximum inhibitory concentration $\left(\mathrm{IC}_{50}\right)$ was 1.48 and $0.94 \mathrm{mg} / \mathrm{ml}$ for 48 and $72 \mathrm{~h}$, respectively (Fig. 1).

SJKJT induced apoptosis in Hep-G2 cells. The Hep-G2 cells were plated in $6 \mathrm{~cm}$ dishes at a density of $1 \times 10^{6}$ cells per dish and were then treated with various concentrations of SJKJT for different durations (48 and $72 \mathrm{~h}$ ). The cell cycles were analyzed by fluorescence-activated cell sorting (FACS). When Hep-G2 cells were cultured with various concentrations $(0$, $0.75,1$ and $1.5 \mathrm{mg} / \mathrm{ml}$ ) of SJKJT for $48 \mathrm{~h}$, the sub-G1 phase percentages were $1.2 \pm 0.15,4.9 \pm 0.59,5.8 \pm 0.32$ and $6.9 \pm 0.35 \%$, respectively. When Hep-G2 cells were cultured with various concentrations $(0,0.5,0.75$ and $1 \mathrm{mg} / \mathrm{ml})$ of SJKJT for $72 \mathrm{~h}$, the sub-G1 phase percentages were $1.5 \pm 0.10,7.3 \pm 0.64,13.7 \pm 1.4$ and $13.0 \pm 0.78 \%$, respectively (Fig. 2A and B). The FACS results showed that treatment with SJKJT induced apoptosis.

Immunocytochemical analysis. Hep-G2 cells were treated with various concentrations $(0,0.75,1$ and $1.5 \mathrm{mg} / \mathrm{ml})$ of
A

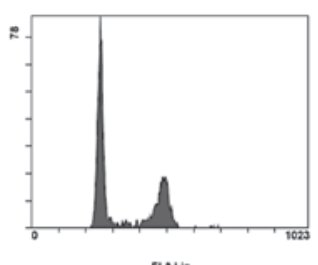

Control

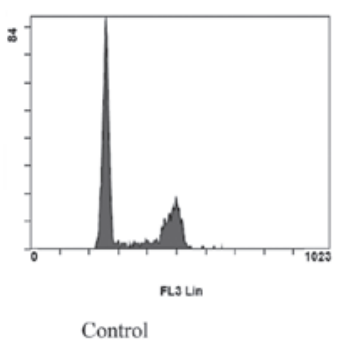

B

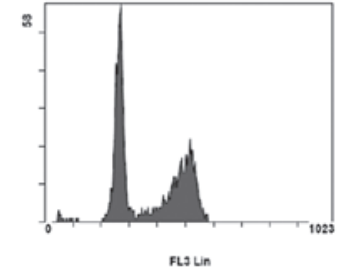

$0.75 \mathrm{mg} / \mathrm{ml}$

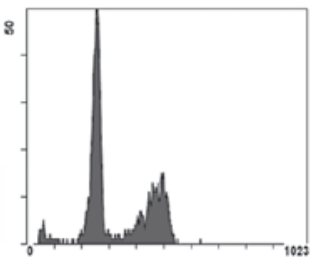

$0.5 \mathrm{mg} / \mathrm{ml}$
$48 \mathrm{~h}$

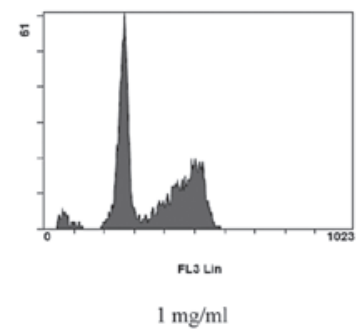

$72 \mathrm{~h}$
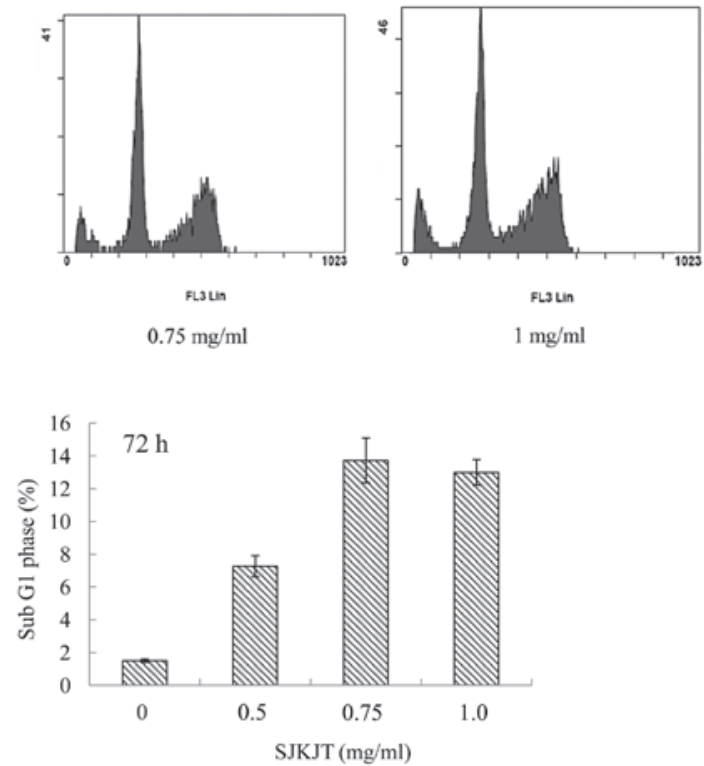

Figure 2. Effect of SJKJT on the cell cycle of Hep-G2 cells. (A) The Hep-G2 cells were treated with SJKJT for various durations. The cell cycles were analyzed by FACS. (B) When Hep-G2 cells were cultured with SJKJT $(0,0.75,1$ and $1.5 \mathrm{mg} / \mathrm{ml})$ for $48 \mathrm{~h}$, the sub-G1 phase percentages were $1.2 \pm 0.15,4.9 \pm 0.59$, $5.8 \pm 0.32$ and $6.9 \pm 0.35 \%$, respectively. Hep-G2 cells were cultured with SJKJT $(0,0.5,0.75 \mathrm{and} 1 \mathrm{mg} / \mathrm{ml})$ for $72 \mathrm{~h}$, the sub-G1 phase percentages were $1.5 \pm 0.10$, $7.3 \pm 0.64,13.7 \pm 1.4$ and 13.0 $\pm 0.78 \%$, respectively. SJKJT, Sann-Joong-Kuey-Jian-Tang; FACS, fluorescence-activated cell sorting. 
A

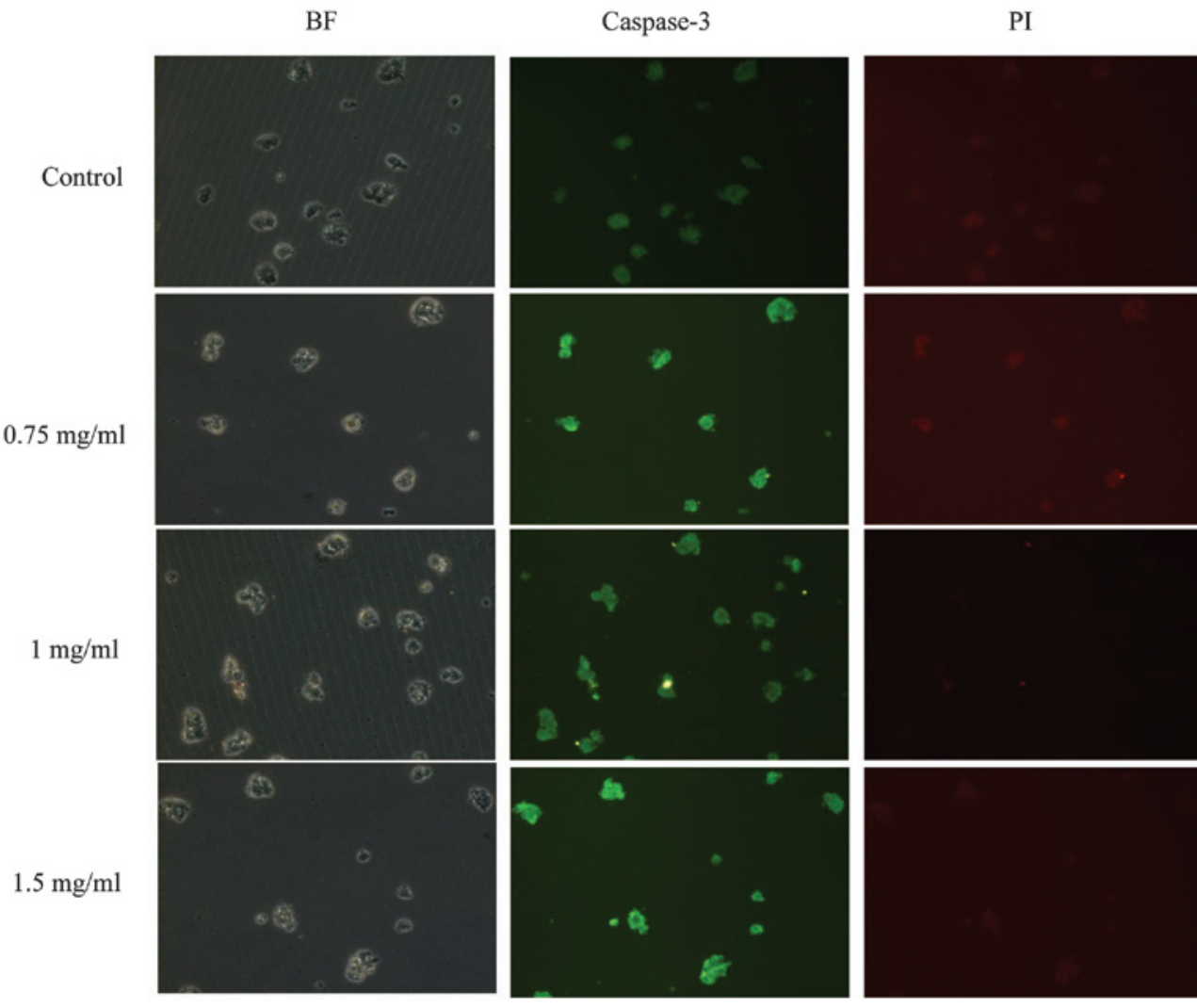

B

$\mathrm{BF}$

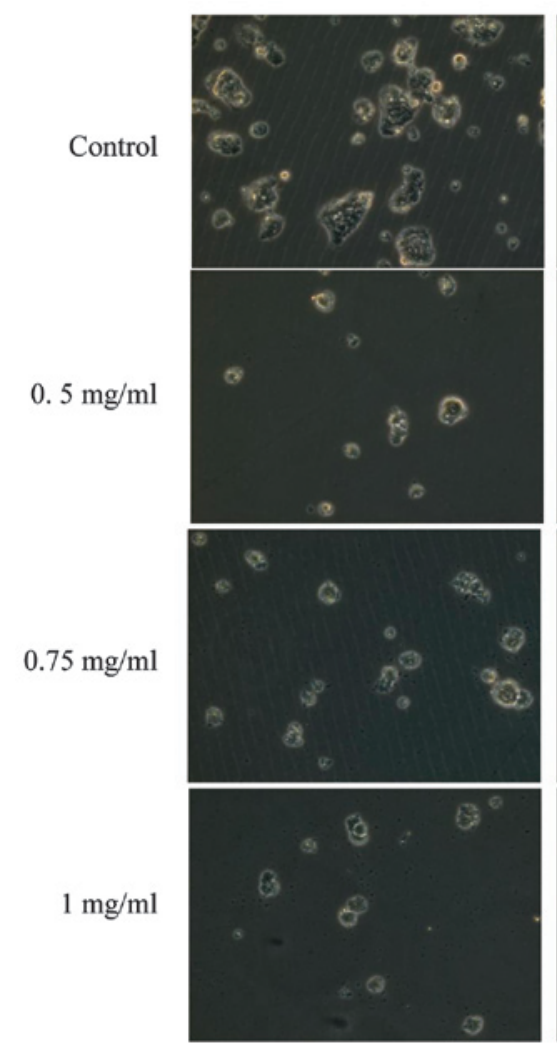

$72 \mathrm{~h}$

Caspase-3
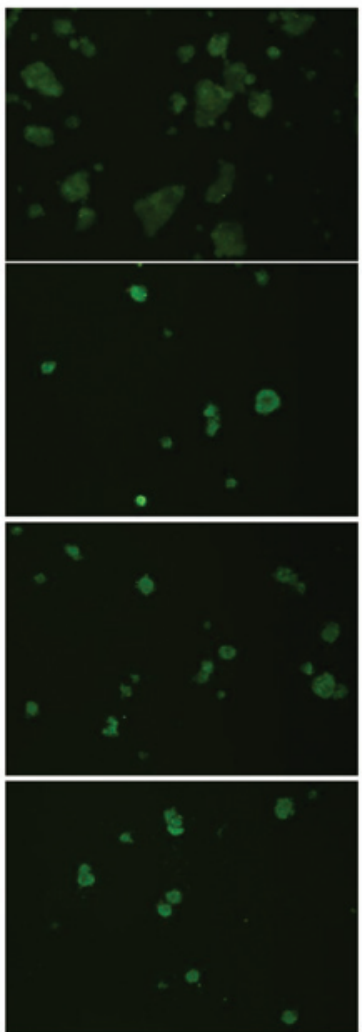

PI
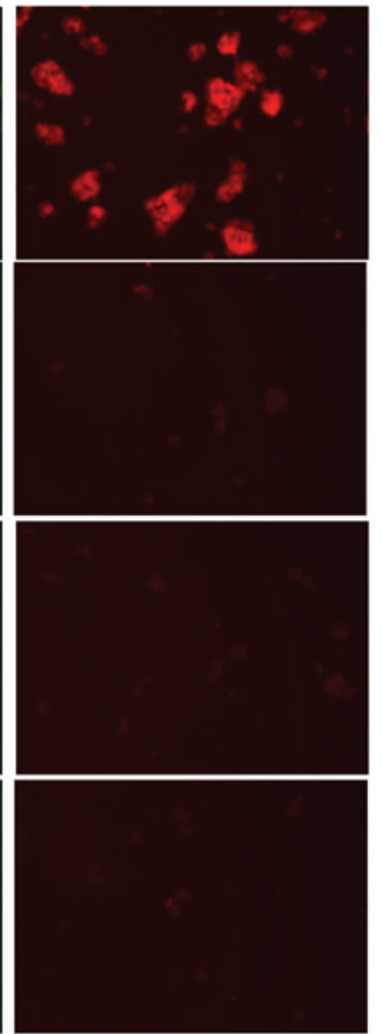

Figure 3. Immunocytochemical analysis. Hep-G2 cells were treated with SJKJT $(0,0.75,1$ and $1.5 \mathrm{mg} / \mathrm{ml})$ for $48 \mathrm{~h}$ or with SJKJT $(0,0.5,0.75 \mathrm{and} 1 \mathrm{mg} / \mathrm{ml})$ for $72 \mathrm{~h}$, and were then fixed with $4 \%$ paraformaldehyde to allow for detection by Caspase 3 antibody. These results revealed that Hep-G2 cells treated with SJKJT have an increased expression of Caspase-3 after (A) $48 \mathrm{~h}$ and (B) $72 \mathrm{~h}$. SJKJT, Sann-Joong-Kuey-Jian-Tang. 
A

$\frac{\operatorname{SJKJT}(\mathrm{mg} / \mathrm{ml})}{0} \begin{array}{lll}0.75 & 1 & 1.5\end{array}$
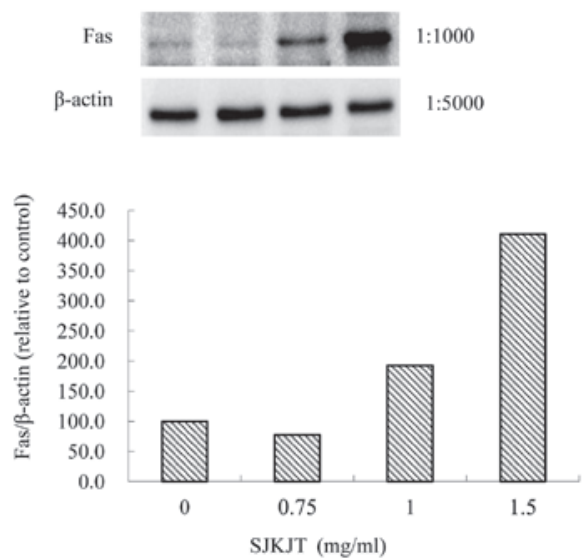

C

$$
\frac{\operatorname{SJKJT}(\mathrm{mg} / \mathrm{ml})}{0} \begin{array}{lll}
0.75 & 1 & 1.5
\end{array}
$$

TNF- $\alpha$
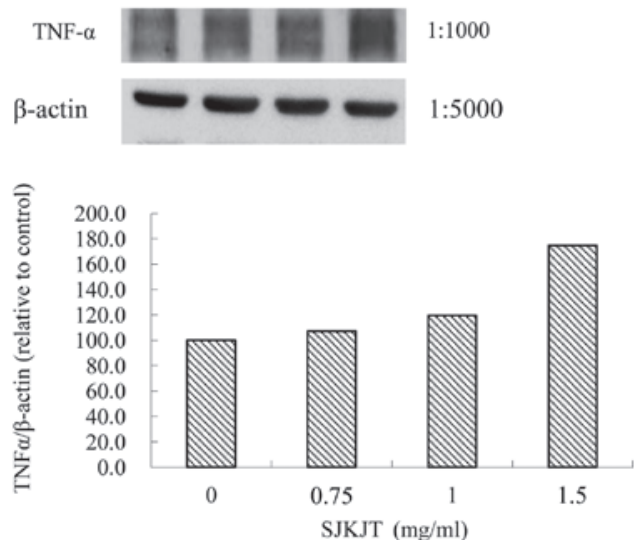

$\mathbf{E}$

$$
\frac{\operatorname{SJKJT}(\mathrm{mg} / \mathrm{ml})}{0.75 \quad 1 \quad 1.5}
$$
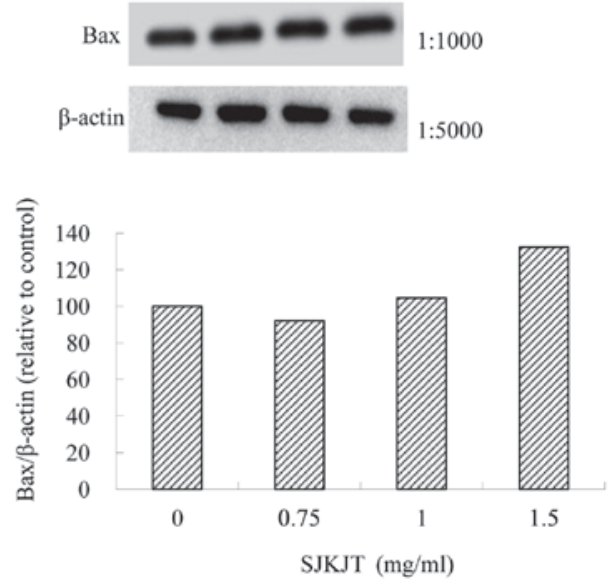

$\mathbf{B}$

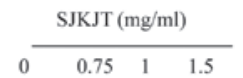

FADD

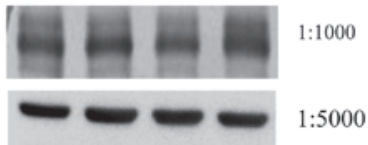

$\beta$-actin

$1: 5000$
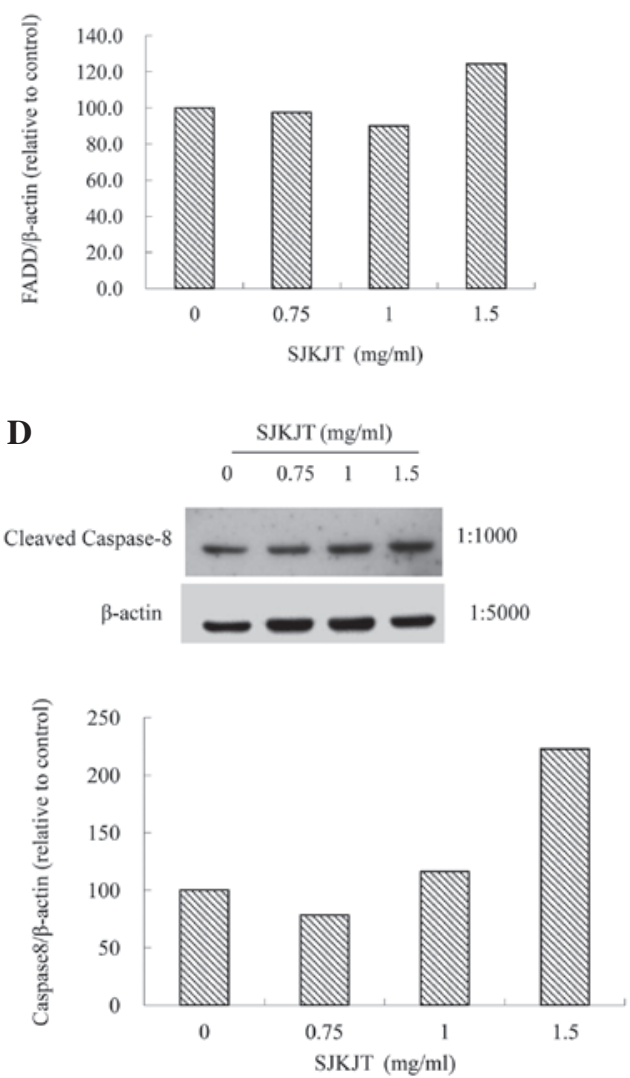

F $\frac{\mathrm{SJKJT}(\mathrm{mg} / \mathrm{ml})}{0} \quad \begin{array}{lll}0.75 & 1 & 1.5\end{array}$

Cleaved Caspase-3

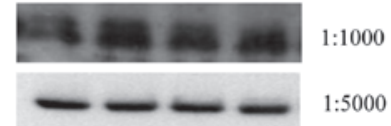

$\beta$-actin 5000

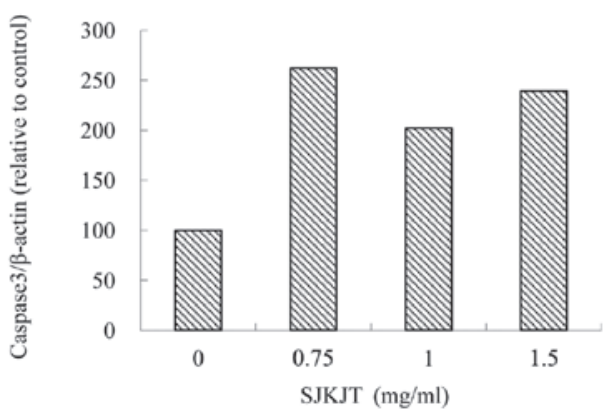

Figure 4. The effects of SJKJT on the protein expression of Fas, TNF- $\alpha$, FADD, Caspase-8, Bax and Caspase-3 in Hep-G2 cells. Hep-G2 cells were treated with $\operatorname{SJKJT}(0,0.75,1$ and $1.5 \mathrm{mg} / \mathrm{ml})$ for $48 \mathrm{~h}$ and the protein expression was evaluated by western blotting. The results showed that SJKJT can increase the protein expression level of (A) Fas, (B) FADD, (C) TNF- $\alpha$, (D) Caspase-8, (E) Bax and (F) Caspase-3. SJKJT, Sann-Joong-Kuey-Jian-Tang.

SJKJT for $48 \mathrm{~h}$ or with various concentrations $(0,0.5,0.75$ and $1 \mathrm{mg} / \mathrm{ml}$ ) of SJKJT for $72 \mathrm{~h}$, and then were fixed with $4 \%$ paraformaldehyde to allow for the detection of Caspase 3 by staining with antibodies. These results revealed that
Hep-G2 cells treated with SJKJT have increased expression of Caspase- 3 at 48 h (Fig. 3A) and 72 h (Fig. 3B), and the effect was dose-dependent. These results suggest that SJKJT induces apoptosis in Hep-G2 cells. 


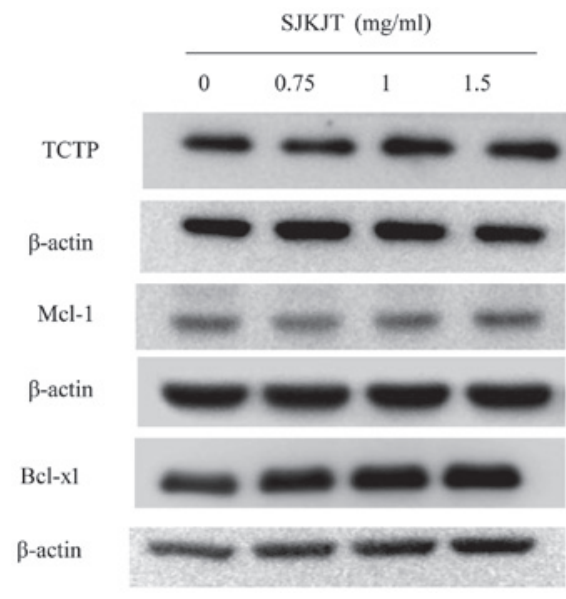

Figure 5. Effects of SJKJT on the protein expression of Mcl-1, TCTP and Bcl-xl in Hep-G2 cells. Hep-G2 cells were treated with SJKJT $(0,0.75,1$ and $1.5 \mathrm{mg} / \mathrm{ml}$ ) for $48 \mathrm{~h}$ and the protein expression was evaluated by western blotting. The protein expression level of Mcl-1, TCTP and Bcl-xl did not change significantly. SJKJT, Sann-Joong-Kuey-Jian-Tang.

$\mathbf{A}$

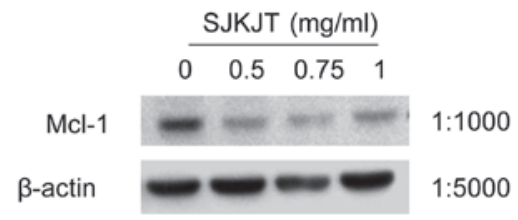

B
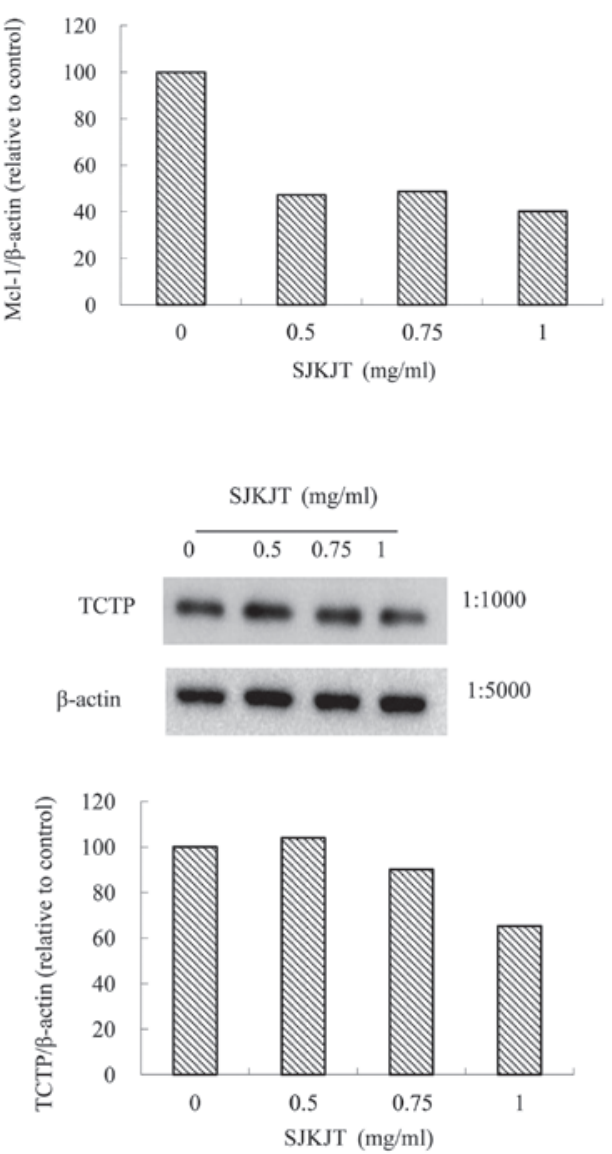

Figure 6. Effects of SJKJT on the protein expression of Mcl-1 and TCTP in Hep-G2 cells. Hep-G2 cells were treated with SJKJT $(0,0.5,0.75$ and $1 \mathrm{mg} / \mathrm{ml}$ ) for $72 \mathrm{~h}$ and the protein expression was evaluated by western blotting. The results showed that SJKJT can decrease the protein expression level of (A) MCl-1 and (B) TCTP. SJKJT, Sann-Joong-Kuey-Jian-Tang.

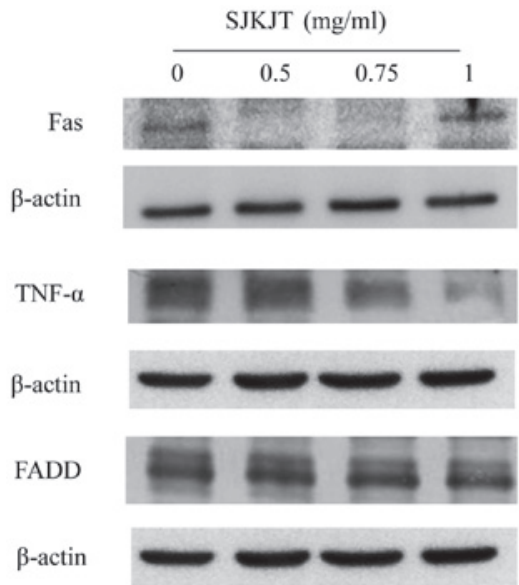

Figure 7. Effects of SJKJT on the protein expression of Fas, TNF- $\alpha$ and FADD in Hep-G2 cells. Hep-G2 cells were treated with SJKJT $(0,0.5,0.75$ and $1 \mathrm{mg} / \mathrm{ml}$ ) for $72 \mathrm{~h}$ and the protein expression was evaluated by western blotting. The results showed that the protein expression of Fas was increased, but TNF- $\alpha$ and FADD did not change significantly. SJKJT, Sann-Joong-Kuey-Jian-Tang.
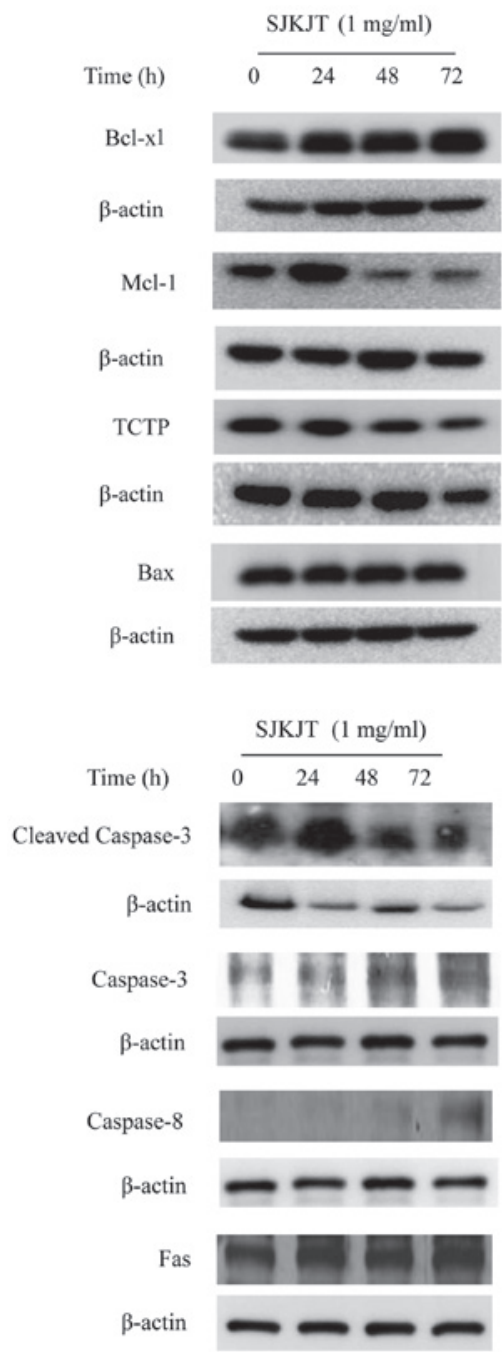

Figure 8. Effects of SJKJT on the protein expression of Bcl-xl, Mcl-1, TCTP, Fas, Caspase- 8 , Caspase- 3 and Bax in Hep-G2 cells. Hep-G2 cells were treated with SJKJT $(1 \mathrm{mg} / \mathrm{ml})$ for different durations $(0,24,48$ and $72 \mathrm{~h})$ and then the protein expression was evaluated by western blotting. The results showed that SJKJT can decrease the protein expression level of (A) Mcl-1 and TCTP, but increase the protein expression level of (B) Bcl-xl, Fas, Caspase-8, Caspase-3 and Bax. SJKJT, Sann-Joong-Kuey-Jian-Tang. 
The effects of SJKJT on the protein expression of Fas, TNF- $\alpha$, FADD, Caspase-8, Bax, Caspase-3, Mcl-1, TCTP and Bcl-xl in Hep-G2 cells. Hep-G2 cells were treated with various concentrations $(0,0.75,1$ and $1.5 \mathrm{mg} / \mathrm{ml})$ of SJKJT for $48 \mathrm{~h}$ and the protein expression levels of Fas, TNF- $\alpha$, FADD, Caspase-8, Bax, Caspase-3, Mcl-1, TCTP and Bcl-xl were evaluated by western blotting. The results demonstrated that SJKJT can increase the protein expression level of Fas (Fig. 4A), FADD (Fig. 4B), TNF- $\alpha$ (Fig. 4C), Caspase-8 (Fig. 4D), Bax (Fig. 4E) and Caspase-3 (Fig. 4F), but the protein expression level of Mcl-1, TCTP and Bcl-xl did not change significantly (Fig. 5). It is well documented that when the Fas receptor binds to an activator, the receptor forms a death-inducing signaling complex, resulting in the active form of Caspase- 8 cleaving and activating Caspase-3, leading to apoptosis $(7,8)$. Tumor necrosis factor $\alpha(\mathrm{TNF}-\alpha)$ is produced by macrophages, and binds to TNF receptor type 1 and activates to form the death-inducing signaling complex, resulting in the recruitment of caspases and subsequently leading to cell apoptosis $(9,10)$.

Hep-G2 cells were treated with various concentrations $(0,0.5,0.75$ and $1 \mathrm{mg} / \mathrm{ml})$ of SJKJT for $72 \mathrm{~h}$ and the protein expression levels of Fas, TNF- $\alpha$, FADD, Caspase-8, Bax, Caspase-3, Mcl-1, TCTP and Bcl-xl were evaluated by western blotting. The results showed that SJKJT can decrease the protein expression level of MCl-1 (Fig. 6A) and TCTP (Fig. 6B). The results also showed that the protein expression level of Fas was increased, but TNF- $\alpha$ and FADD did not change significantly (Fig. 7). It is well documented that TCTP overexpression inhibits apoptosis by binding to Mcl-1 and antagonizing Bax (4,11-13). Our results showed that SJKJT inhibits TCTP and Mcl-1 expression in Hep-G2 cells. One of the molecular mechanisms by which SJKJT inhibits Hep-G2 cells may be through decreasing TCTP and Mcl-1 expression.

Hep-G2 cells were treated with SJKJT $(1 \mathrm{mg} / \mathrm{ml})$ for different durations $(0,24,48$ and $72 \mathrm{~h})$ and then the protein expression levels of Fas, Caspase-8, Caspase-3, Bcl-xl, Mcl-1, TCTP and Bax were evaluated by western blotting. The results revealed that increasing the treatment duration of SJKJT can decrease the protein expression level of Mcl-1 and TCTP (Fig. 8A), but increase the protein expression level of Bcl-xl, Fas, Caspase-8, Caspase-3 and Bax (Fig. 8B). SJKJT did not demonstrate significant toxicity in normal cells and it has been well documented to inhibit human breast cancer by inducing apoptosis (14). Our results also demonstrated that SJKJT induces apoptosis in Hep-G2 cells. The molecular mechanisms may be through the downregulation of protein expression of TCTP and Mcl-1, but upregulation of Fas, TNF- $\alpha$, Caspase-8,
Caspase-3 and Bax expression. This is the first study to demonstrate that SJKJT inhibits human hepatocellular carcinoma Hep-G2 cells through the extrinsic and intrinsic pathways. The therapeutic potential for SJKJT to treat human HCC requires further study.

\section{Acknowledgements}

This study was supported by grant 100-CCH-ICO-06-3 from Changhua Christian Hospital.

\section{References}

1. Jemal A, Bray F, Center MM, Ferlay J, Ward E and Forman D: Global cancer statistics. CA Cancer J Clin 61: 69-90, 2011.

2. Statistics of Causes of Death, 2010. Department of Health, Executive Yuan, Taipei, Taiwan, R.O.C, p153, 2012.

3. Leung TW and Johnson PJ: Systemic therapy for hepatocellular carcinoma. Semin Oncol 28: 514-520, 2001.

4. Hsu YL, Yen MH, Kuo PL, et al: San-Zhong-Kui-Jian-Tang, a traditional Chinese medicine prescription, inhibits the proliferation of human breast cancer cells by blocking cell cycle progression and inducing apoptosis. Biol Pharm Bull 29: 2388-2394, 2006.

5. Cheng CY, Lin YH and Su CC: Sann-Joong-Kuey-Jian-Tang increases the protein expression of microtubule-associated protein II light chain 3 in human colon cancer colo 205 cells. Mol Med Rep 2: 707-711, 2009.

6. Cheng CY, Lin YH and Su CC: Sann-Joong-Kuey-Jian-Tang up-regulates the protein expression of Fas and TNF- $\alpha$ in colo 205 cells in vivo and in vitro. Mol Med Rep 3: 63-67, 2010.

7. C Cohen GM: Caspases, the executioners of apoptosis. Biochem J 326: 1-16, 1997

8. L Lowe SW, Cepero E and Evan G: Intrinsic tumour suppression. Nature 432: 307-315, 2004.

9. Carswell EA, Old LJ, Kassel RL, et al: An endotoxin-induced serum factor that causes necrosis of tumors. Proc Natl Acad Sci USA 72: 3666-3670, 1975.

10. Gaur U and Aggarwal BB: Regulation of proliferation, survival and apoptosis by members of the TNF superfamily. Biochem Pharmacol 66: 1403-1408, 2003

11. Graidist P, Phongdara A and Fujise K: Antiapoptotic protein partners fortilin and MCL1 independently protect cells from 5-fluorouracil-induced cytotoxicity. J Biol Chem 279: 40868-40875, 2004.

12. Liu H, Peng HW, Cheng YS, et al: Stabilization and enhancement of the antiapoptotic activity of mcl-1 by TCTP. Mol Cell Biol 25: 3117-3126, 2005.

13. Zhang D, Li F, Weidner D, et al: Physical and functional interaction between myeloid cell leukemia 1 protein (MCL1) and Fortilin. The potential role of MCL1 as a fortilin chaperone. J Biol Chem 277: 37430-37438, 2002.

14. Susini L, Besse S, Duflaut D, et al: TCTP protects from apoptotic cell death by antagonizing bax function. Cell Death Differ 15: 1211-1220, 2008. 